\title{
PENGAYAAN KOMPOS TANDAN KOSONG KELAPA SAWIT DENGAN LUMPUR LAUT DAN BIOCHAR SEKAM PADI PADA TANAMAN PADI DI TANAH SULFAT MASAM
}

\author{
Sri Andayani ${ }^{1}$, Edy Syafril Hayat ${ }^{1}$ \\ Staf Pengajar Fakultas Pertanian, Universitas Panca Bhakti \\ Jl. Kom Yos Sudarso Pontianak Kalimantan Barat 78113 \\ Email : sriyani.upb@gmail.com
}

\begin{abstract}
ABSTRAK
Tanah sulfat masam merupakan salah satu tanah suboptimal, memiliki potensi untuk pengembangan budidaya tanaman, namun memiliki keterbatasan : rendahnya kadar pH tanah, hara N,P dan K, kapasitas tukar kation, kejenuhan basa, tingginya kadar $\mathrm{Al}, \mathrm{Fe}, \mathrm{Mn}$, maka alternatif penggunaan bahan organik tersedia lokal seperti tandan kosong sawit (TKKS) berpeluang dimanfaatkan menjadi kompos yang diperkaya untuk memperbaiki kesuburan tanah tersebut. Belum ada rekomendasi khusus tentang aplikasi kompos yang diperkaya pada tanah sulfat masam. Anjuran umum yaitu aplikasi kompos secara tunggal dengan dosis 5-15 ton/ha. Sehingga perlu metode baru melalui perlakuan pengayaan kompos (compost enrichment) dengan amalioran yang tersedia lokal seperti lumpur laut dan biochar sekam padi. Penelitian bertujuan : menghasilkan dosis terbaik kompos TKKS diperkaya yang dapat meningkatkan pertumbuhan dan hasil tanaman padi. Penelitian ini menggunakan metode eksperimen (experiment design), dengan Rancangan Acak Lengkap (RAL). Penelitian dilaksanakan di Desa Sungai Rengas Kecamatan Sungai Kakap, Kabupaten Kubu Raya, mulai bulan Maret sampai Juli 2018. Hasil penelitian menunjukkan bahwa perlakuan $t_{3}$ (aplikasi kompos TKKS, lumpur laut sebanyak 15 ton/ha) memberikan pengaruh nyata terhadap jumlah anakan produktif tanaman padi yaitu sebanyak 18,58 anakan. Selanjutnya untuk variabel tinggi tanaman padi, perlakuan t3 juga menghasilkan rata-rata tertinggi yaitu $89,33 \mathrm{~cm}$. Perlakuan t8 (aplikasi kompos TKKS, lumpur laut dan arang sekam padi sebanyak 10 ton/ha) menghasilkan berat gabah tertinggi yaitu 346,3 $\mathrm{gram} / \mathrm{m}^{2}$, dan perlakuan t9 (aplikasi sebanyak 15 ton/ha ketiga bahan tersebut) menghasilkan berat gabah 1000 butir tertinggi yaitu 24,989 gram.
\end{abstract}

Kata kunci : Kompos, Lumpur Laut, Tanah Sulfat Masam

\section{PENDAHULUAN}

Pemanfaatan lahan-lahan sub-optimal untuk pembukaan dan pencetakan areal persawahahan baru menghadapi masalah serius. Berdasarkan kebutuhan pangan nasional terutama padi, jagung, dan kedelai, maka hingga tahun 2025 dibutuhkan 4,7 juta hektar (ha) lahan bukaan baru, dan untuk menjamin produksi beras hingga tahun 2025, dibutuhkan perluasan areal sawah sekitar 1,4 hektar (ha). Saat ini luas lahan sawah eksisting sekitar 8,1 juta ha cenderung menciut akibat konversi ke lahan nonsawah, sementara itu kemampuan pemerintah dalam pencetakan lahan sawah hanya sekitar 30-40 ribu hektar setiap 
tahun (Haryono, 2013). Oleh sebab itu Indonesia saat ini tidak lagi punya banyak pilihan dalam rangka mewujudkan ketahanan pangan nasional selain memanfaatkan lahan-lahan suboptimal yang masih tersedia. Salah satu lahan suboptimal yang dapat dimanfaatkan untuk dibudidaya tanaman padi adalah lahan sulfat masam yang luasnya di Indonesia mencapai 6,70 juta hektar (Suriadikarta, 2005).

Pengembangan pertanian di lahan sulfat masam sering menghadapi beberapa permasalahan seperti rendahnya $\mathrm{pH}$ tanah dan fosfat tersedia, serta tingginya kandungan Fe (Purnomo, E. A. Mursyid, M. Syarwani, A. Jumberi, Y Hashidoko, T. Hasegawa S, Homna, dan M. Osaki, 2005). Tanah sulfat masam berkembang dari bahan induk yang kaya akan senyawa pirit $\left(\mathrm{FeS}_{2}\right)$. Akibat dari daya dukung kesuburan kimia yang rendah, maka salah satu kunci keberhasilan pengelolaan alahan sulfat masam adalah penggunaan amelioran. Aplikasi kompos tandan kosong kelapa sawit (TKKS) yang diperkaya (compost enrichment) merupakan pilihan teknologi yang tepat untuk mengatasi kendala tanah tersebut. Pengayaan kompos TKKS dengan lumpur laut dan biochar sekam padi dapat memberikan solusi dalam pengelolaan lahan berkelanjutan, mengingat bahan- bahan tersebut banyak tersedia secara lokal di sentra-sentra pertanian, terutama di luar pulau Jawa. Bertolak dari pemikiran tersebut, maka perlu dilakukan penelitian guna membuat formulasi kompos TKKS diperkaya (compost enrichment) yang tepat untuk lahan sulfat masam serta melihat pengaruh aplikasi compost enrichment dengan lumpur laut dan biochar sekam padi terhadap perbaikan sifat kimia tanah, sehingga akan meningkatkan kesuburan tanah sulfat masam.

Saat ini penggunaan kompos yang direkomendasikan umumnya adalah penggunaan kompos tunggal dengan kisaran dosis 5-15 ton per ha. Dari hasil penelitian pendahuluan yang telah dilakukan yaitu aplikasi kompos tandan kosong kelapa sawit (TKKS) sebanyak 5 ton/ha yang dikombinasikan dengan biomassa Chromolaena odorata sebanyak 10 ton/ha pada tanah Sulfaquent (sulfat masam) dapat meningkatkan $\mathrm{pH}$ dari 5,26 menjadi 6,22 (Hayat,E.S dan S. Andayani, 2014). Berkaitan dengan itu diperlukan upaya untuk meningkatkan kualitas kompos melalui metode pengayaan kompos (compost enrichment) dengan penambahan amelioran lain yang tersedia cukup banyak secara lokal. Adapun bahan pengaya kompos yang dapat dimanfaatkan antara lain lumpur laut dan biochar sekam padi. 
Pemanfaatan biochar sekam padi yang dikombinasikan dengan Chromolaena odorata dan jerami padi pada 6 minggu setelah inkubasi, dapat meningkatkan $\mathrm{pH}$, C-organik, P-tersedia dan kapasitas tukar kation (KTK) dan menurunkan Al-dd serta Fe-larut (Masulili A., Suryantini, A.Tutik P.I, 2014). Selanjutnya untuk pemanfaatan lumpur laut sebagai amelioran telah dilakukan penelitian oleh Sulistiyowati dan D. Suswati (2010), bahwa lumpur laut dapat meningkatkan kejenuhan basa (KB), sehingga dapat meningkatkan kesuburan tanah.

Penelitian ini bertujuan untuk : menemukan metode yang mudah dan murah dalam pengayaan kompos TKKS melalui penambahan lumpur laut dan biochar sekam padi, menghasilkan produk kompos diperkaya yang dapat meningkatkan kesuburan tanah sulfat masam, menentukan dosis spesifik lokasi yang tepat untuk kompos diperkaya yang diaplikasikan di tanah sulfat masam sehingga dapat meningkatkan pertumbuhan dan hasil tanaman padi.

\section{BAHAN DAN METODE}

\section{Tempat dan Waktu Penelitian}

Penelitian dilaksakan di Desa Sungai Rengas Kecamatan Sungai Kakap mulai Februari 2018- Agustus 2018.
Metode yang digunakan adalah metode percobaan (experimental design), menggunakan Rancangan Acak Lengkap (RAL), yang terdiri dari 9 perlakuan dosis kompos Tandan kosong kelapa sawit, lumpur laut dan biochar sekam padi diberi kode $\mathrm{T}$ yaitu $: \mathrm{t}_{1}=$ Kompos TKKS + lumpur laut $=5$ ton $/$ ha $=500 \mathrm{gr} /$ petak,$\quad t_{2}$ $=$ Kompos TKKS + lumpur laut $=10$ ton $/$ ha $=1000$ gr/petak, $\mathrm{t}_{3}=$ KomposTKKS + lumpur laut $=15$ ton $/$ ha $=1500 \mathrm{gr} /$ petak, $\mathrm{t}_{4}=$ Kompos TKKS + arang sekam padi $=$ 5 ton $/$ ha $=500$ gr $/$ petak, $t_{5}=$ Kompos $\mathrm{TKKS}+$ arang sekam padi $=10$ ton $/ \mathrm{ha}=$ $1000 \mathrm{gr} /$ petak, $\mathrm{t}_{6}=$ Kompos TKKS + arang sekam padi $=15$ ton $/$ ha $=1500 \mathrm{gr} /$ petak, $\mathrm{t}_{7}=$ Kompos TKKS + lumpur laut + arang sekam padi $=5$ ton $/$ ha $=500 \mathrm{gr} /$ petak, $\mathrm{t}_{8}=$ Kompos TKKS + lumpur laut + arang sekam padi $=10$ ton $/$ ha $=1000 \mathrm{gr} /$ petak, t9 $=$ Kompos TKKS + lumpur laut + arang sekam padi $=15$ ton $/$ ha $=1500$ gr $/$ petak . Setiap kombinasi perlakuan diulang 3 kali sehingga diperoleh 27 satuan percobaan. Untuk mengetahui pengaruh perlakuan terhadap variabel pengamatan dilakukan analisis keragaman/ analisis of variance (ANOVA), dan apabila dari ANOVA terdapat perbedaan yang signifikan maka dilanjutkan dengan uji Beda Nyata Jujur (BNJ) pada taraf $5 \%$. 
Model matematik dari rancangan yang digunakan dalam penelitian ini adalah sebagai berikut :

Yij $=\mu \mathrm{i}+\sum \mathrm{ij}$, dimana :

Yij = Respon variable pengamatan

$\mu \quad=$ Nilai tengah populasi

$\sum \mathrm{ij}=$ galat percobaan dari perlakuan ke-i, pada pengamatan ke- $\mathrm{j}$

Pelaksanaan penelitian dimulai dari persiapan media tanam yang terdiri atas tanah sulfat masam. Tanah dibersihkan dari gulma, setelah itu dilakukan pengolahan tanah dengan cara dibajak hingga tanah melumpur, selanjutnya dibuat petakan dengan ukuran $1 \mathrm{~m}$ x $1 \mathrm{~m}$ sebanyak 27 petak. Benih padi yang digunakan adalah varietas Inpara 3, disemai di lokasi terpisah bersamaan saat mulai pengolahan tanah. Setelah pengolahan tanah, diaplikasikan kompos yang diperkaya sesuai dosis perlakuan dengan cara ditabur merata diatas petakan kemudian dibenamkan dengan mengaduk dan membalik tanah tersebut. Penanaman semaian dilakukan 1 minggu setelah aplikasi kompos diperkaya, dengan jarak tanam $20 \mathrm{~cm} \times 20 \mathrm{~cm}$, sehingga dalam satu petakan diperoleh 25 rumpun tanaman padi. Pemupukan susulan dilakukan sesuai dosis anjuran, dilakukan pula pengendalian hama dan penyakit sesuai rekomendasi setempat. Kegiatan pemeliharaan lainnya dilakukan sesuai pedoman dan rekomendasi, hingga tanaman panen.

Pengamatan dilakukan terdiri dari beberapa tahap yaitu : (1) Analisis sifat fisik dan kimia tanah sebelum aplikasi kompos TKKS yang diperkaya, (2) analisis kimia kompos TKKS dan kompos TKKS yang diperkaya, (3) analisis sifat kimia tanah setelah aplikasi kompos TKKS yang diperkaya ( $\mathrm{pH}, \mathrm{C}$-organik, KB, KTK, N, P, K), (4) Pengamatan faktor pertumbuhan dan hasil tanaman padi (tinggi tanaman, jumlah anakan produktif, hasil per petak, berat 1000 butir), (5) Faktor lingkungan : suhu, kelembaban udara, dan curah hujan.

\section{HASIL DAN PEMBAHASAN}

Variabel yang diamati :

\section{a. Sifat kimia tanah}

Pengukuran $\mathrm{pH}$ tanah dilakukan pada akhir penelitian, yang dilakukan dengan mengambil tanah secara komposit pada setiap perlakuan. Hasil analisis keragaman pengukuran $\mathrm{pH}$ tanah dapat dilihat pada Tabel 1 berikut : 
Tabel 1. Analisis Keragaman Pengayaan Kompos Tandan Kosong Kelapa Sawit (TKKS) Dengan Lumpur Laut Dan Biochar Sekam Padi Untuk Meningkatkan Pertumbuhan Dan Hasil Tanaman Padi Pada Tanah Sulfat Masam terhadap pH Tanah

\begin{tabular}{lcccccc}
\hline $\begin{array}{c}\text { Sumber } \\
\text { Keragaman }\end{array}$ & $\begin{array}{c}\text { Deraj } \\
\text { at Bebas }\end{array}$ & $\begin{array}{c}\text { Jumlah } \\
\text { Kuadrat }\end{array}$ & $\begin{array}{c}\text { Kuadrat } \\
\text { Tengah }\end{array}$ & F. Hitung & \multicolumn{2}{c}{ F Tabel } \\
\hline Perlakuan & 8 & 0.18 & 0.02 & $0.78^{\text {tn }}$ & 2.51 & $1 \%$ \\
Galat & 18 & 0.52 & 0.03 & & & \\
\hline Total & 26 & 0.70 & KK $=3.68 \%$ & & & \\
\hline
\end{tabular}

Sumber: Hasil Analisis Data2018

Keterangan : tn (berpengaruh tidak nyata)

Dari Tabel 1. Terlihat perlakuan yang diberikan berpengaruh tidak nyata terhadap peningkatan $\mathrm{pH}$ tanah. Jika dilihat dari rerata $\mathrm{pH}$ tanah setiap perlakuan, $\mathrm{t} 2$ menunjukkan rerata $\mathrm{pH}$ tanah yang tertinggi diantara perlakuan lainnya yaitu sebesar 4,81. Selanjutnya dilakukan pula analisis keragaman terhadap Corganik tanah, KTK, N, P dan $\mathrm{K}$ pada tanah setelah diberi perlakuan. Dari hasil analisis keragaman terhadap veriabel tersebut juga menunjukkan pengaruh yang tidak nyata. Jika dilihat dari rerata setiap perlakuan, untuk perlakuan t4 memberikan hasil tertinggi terhadap variabel C-organik $(8,31 \%)$, KTK $\left(31,58 \mathrm{cmol}(+) \mathrm{kg}^{-1}\right)$ dan $\mathrm{N}$ $(0,88 \%)$, perlakuan t8 memberikan hasil tertinggi untuk variabel Kejenuhan basa (26.63\%) dan P tersedia (18,35 ppm), dan perlakuan t9 memberikan hasil tertinggi untuk variabel $\mathrm{K}$ tanah $(0,253 \mathrm{cmol}(+) \mathrm{kg}$ 1). Selanjutnya untuk menggambarkan pengaruh dari aplikasi kompos tandan kosong kelapa sawit (TKKS) yang sudah diperkaya dengan lumpur laut dan $b$ iochar sekam padi dibuat grafik sebagai berikut :

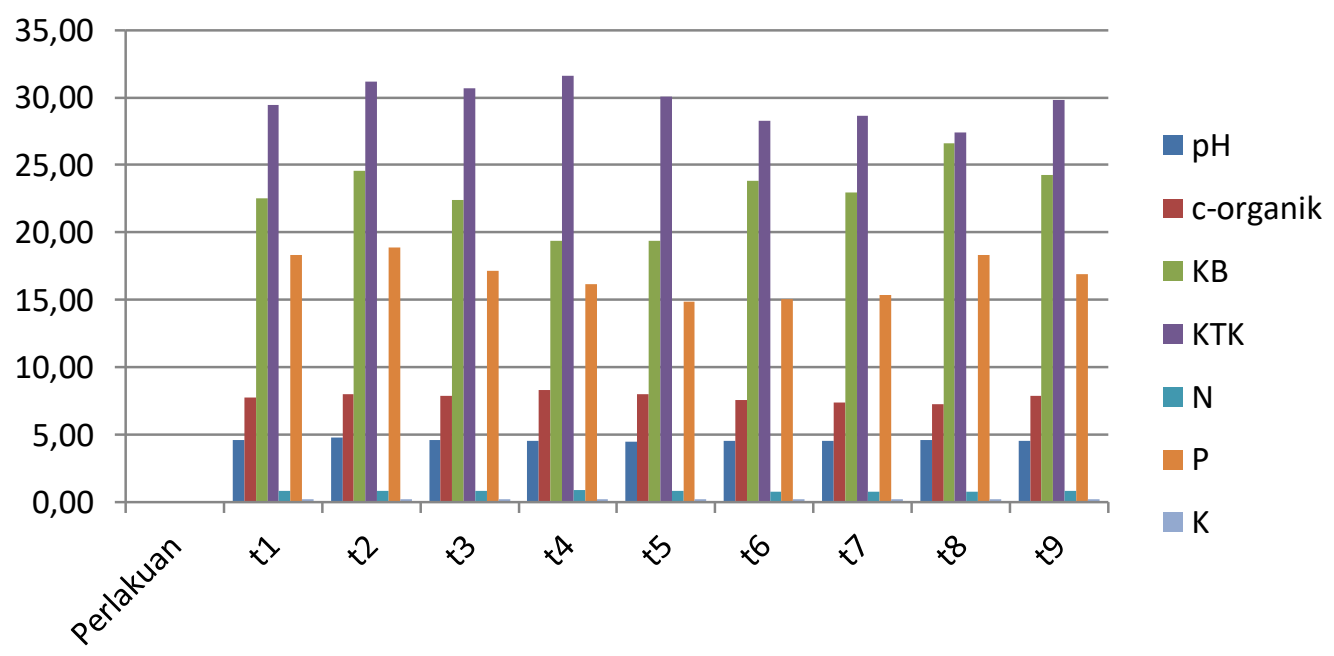

Gambar 1.Pengaruh Aplikasi Perlakuan Terhadap Sifat Kimia tanah 


\section{b. Pertumbuhan dan hasil tanaman padi}

Pengukuran pertumbuhan dan hasil Sawit yang diperkaya memberikan tanaman padi meliputi tinggi tanaman, pengaruh yang nyata terhadap jumlah jumlah anakan produktif, hasil per petak anakan produktif (dapat dilihat pada Tabel dan berat 1000 butir padi.

Berdasarkan data yang didapat ullanunall allallsis nelagallall. llasll analisis keragaman menunjukkan bahwa 2) dan memberikan pengaruh yang tidak nyata terhadap variabel tinggi tanaman, Ilasil pel petan hall velal ivUy vulll pauı (dapat dilihat pada Tabel 3).

perlakuan Kompos Tandan Kosong Kelapa

Tabel 2. Analisis Keragaman Pengayaan Kompos Tandan Kosong Kelapa Sawit (TKKS) Dengan Lumpur Laut Dan Biochar Sekam Padi Untuk Meningkatkan Pertumbuhan Dan Hasil Tanaman Padi Pada Tanah Sulfat Masam terhadap Jumlah Anakan Produktif

\begin{tabular}{|c|c|c|c|c|c|c|}
\hline \multirow{2}{*}{$\begin{array}{r}\text { Sumber } \\
\text { Keragaman }\end{array}$} & \multirow{2}{*}{$\begin{array}{r}\text { Deraj } \\
\text { at Bebas }\end{array}$} & \multirow{2}{*}{$\begin{array}{l}\text { Jumlah } \\
\text { Kuadrat }\end{array}$} & \multirow{2}{*}{$\begin{array}{l}\text { Kuadrat } \\
\text { Tengah }\end{array}$} & \multirow[t]{2}{*}{ F. Hitung } & \multicolumn{2}{|c|}{ F Tabel } \\
\hline & & & & & $5 \%$ & $1 \%$ \\
\hline Perlakuan & 8 & 78.52 & 9.81 & $2.93^{t^{*}}$ & 2.51 & 3.71 \\
\hline Galat & 18 & 60.25 & 3.35 & & & \\
\hline Total & 26 & 138.77 & $\mathrm{KK}=11.5$ & & & \\
\hline
\end{tabular}

Tabel 3. Hasil Uji Beda Nyata Jujur (BNJ) Pengayaan Kompos Tandan Kosong Kelapa Sawit (TKKS) Yang Di Perkaya Dengan Lumpur Laut Dan Biochar Sekam Padi Terhadap Jumlah Anakan Produktif (anakan)

\begin{tabular}{rlc}
\hline Perlakuan & Rerata & Tanda Beda \\
$\mathrm{t}_{4}$ & 12.67 & $\mathrm{a}$ \\
$\mathrm{t}_{1}$ & 14.50 & $\mathrm{ab}$ \\
$\mathrm{t}_{6}$ & 14.58 & $\mathrm{ab}$ \\
$\mathrm{t}_{7}$ & 15.25 & $\mathrm{ab}$ \\
$\mathrm{t}_{5}$ & 16.50 & $\mathrm{ab}$ \\
$\mathrm{t}_{8}$ & 16.67 & $\mathrm{ab}$ \\
$\mathrm{t}_{9}$ & 17.08 & $\mathrm{ab}$ \\
$\mathrm{t}_{2}$ & 17.33 & $\mathrm{ab}$ \\
$\mathrm{t}_{3}$ & 18.58 & $\mathrm{~b}$ \\
\hline
\end{tabular}

Sumber : Hasil Analisis Data 2018

Keterangan : Angka-Angka yang diikuti huruf yang sama menunjukan berbeda tidak nyata pada uji BNJ 5\% 
Hasil analisis keragaman pada Tabel 2 menunjukan bahwa perlakuan yang diberikan memberikan pengaruh yang nyata terhadap jumlah anakan produktif. Untuk mengetahui perbedaan masingmasing taraf perlakuan pupuk kompos tandan kosong kelapa sawit yang diperkaya dengan lumpur laut dan biochar sekam padi dilakukan uji Beda Nyata Jujur (BNJ) pada taraf 5\% seperti terlihat pada Tabel 3.

Hasil uji BNJ 5\% diketahui bahwa ratarata jumlah anakan produktif tanaman padi yang dihasilkan pada taraf perlakuan t3 berbeda nyata dengan taraf perlakuan $\mathrm{t} 4$, dan tidak berbeda nyata dengan perlakuan

Hasil analisis keragaman perlakuan kompos tandan kosong kelapa sawit yang diperkaya dengan lumpur laut dan biochar sekam padi terhadap tinggi tanaman, hasil padi per petak dan berat 1000 butir padi menunjukkan pengaruh yang tidak nyata.

Namun jika dilihat dari rerata tinggi tanaman padi setiap perlakuan seperti ditunjukkan pada gambar 2, bahwa perlakuan t6 dengan dosis (15 ton $/$ ha $=$ 1500 gram/petak) yaitu tandan kosong kelapa sawit 750 gram dan biochar sekam padi 750 gram/petak menghasilkan rerata tinggi tanaman yang relatif tinggi yaitu $67,67 \mathrm{~cm}$ dibandingkan dengan taraf perlakuan yang lain. Untuk hasil padi per petak yang tertinggi ditunjukkan oleh $\mathrm{t} 1, \mathrm{t} 6, \mathrm{t} 7, \mathrm{t} 5, \mathrm{t} 8, \mathrm{t} 9$ dan $\mathrm{t} 2$. Taraf perlakuan $\mathrm{t} 3$ dengan dosis $(15$ ton $/$ ha $=1500$ gr/petak $)$ menghasilkan jumlah anakan produktif terbanyak sebesar 18,58 anakan, sedangkan yang terendah taraf perlakuan t4dengan dosis $(5$ ton $/$ ha $=500 \mathrm{gr} /$ petak $)$ menghasilkan jumlah anakan produktif terendah yaitu 12,67 anakan.

Rendahnya perlakuan t4 ini disebabkan karena tanaman padi terkena serangan hama tikus. Serangan hama tikus ini menyerang anakan padi sejak berumur 60 hari setelah tanam, dan akibat dari serangan hama tikus rerata perlakuan t4 menjadi rendah.

perlakuan $\mathrm{t} 8$ dengan dosis (10 ton/ha = 1000 gram/petak) yaitu tandan kosong kelapa sawit 333,33, lumpur laut 333,33 gram dan biochar sekam padi 333,33 gram/petak menghasilkan rerata hasil per petak yang relatif lebih tiunggi dari perlakuan lainnya yaitu seberat 346,333 gr. Untuk hasil berat 1000 butir padi yang tertinggi ditunjukkan oleh perlakuan t9 dengan dosis $(15$ ton $/$ ha $=1500$ gram/petak) yaitu tandan kosong kelapa sawit 500 gram, lumpur laut 500 gram dan biochar sekam padi 500 gram/petak menghasilkan rerata hasil per petak yang relatif lebih tiunggi dari perlakuan lainnya yaitu seberat 24,989 gr. 


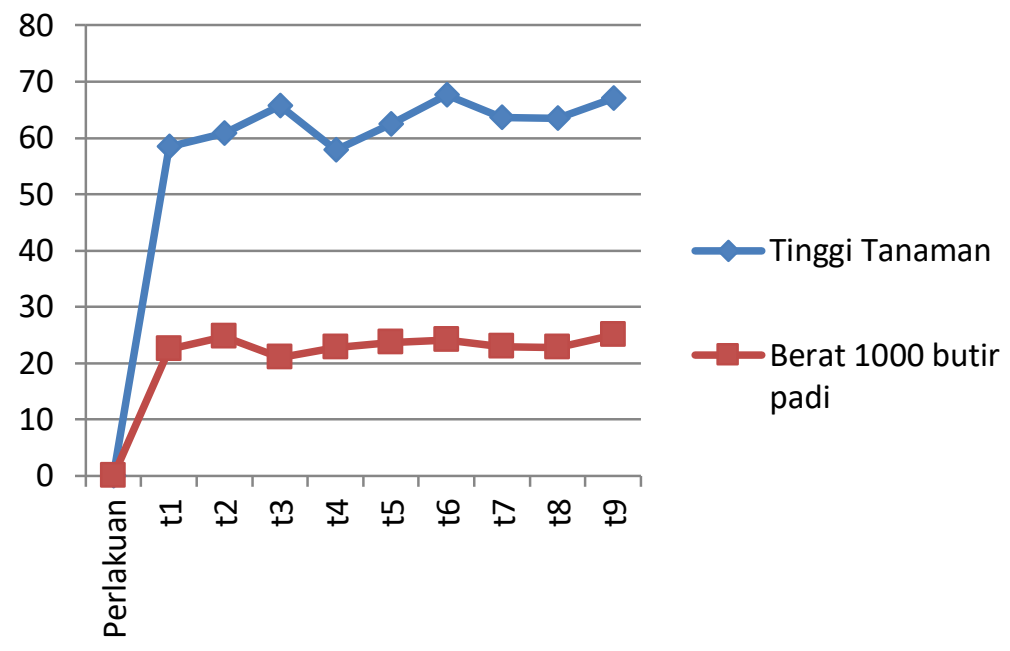

Gambar 2.Pengaruh Aplikasi Perlakuan Terhadap Tinggi Tanaman dan Berat 1000 Butir Padi

\section{Rerata}

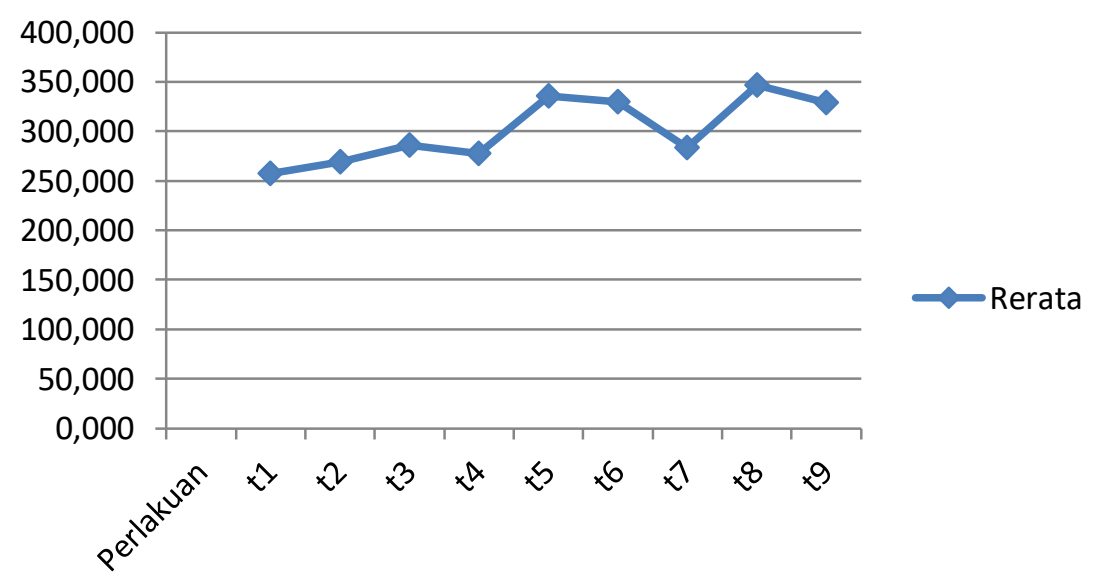

Gambar 3.Pengaruh Aplikasi Perlakuan Terhadap Hasil padi per petak

Tandan kosong kelapa sawit dapat dimanfaatkan sebagai sumber pupuk organik yang memiliki kandungan unsur hara yang dibutuhkan oleh tanah dan tanaman. Tandan kosong kelapa sawit mencapai $23 \%$ dari jumlah pemanfaatan limbah kelapa sawit tersebut sebagai alternatif pupuk organik.

\section{c. Faktor lingkungan}

Faktor lingkungan yang diamati meliputi suhu, kelembaban udara, dan curah hujan. Semua faktor lingkungan tersebut sudah memenuhi syarat tumbuh tanaman padi. Rata-rata suhu udara selama penelitian berkisar antara $26,70{ }^{\circ} \mathrm{C}$ sampai $31,50{ }^{\circ} \mathrm{C}$, rata-rata kelembaban udara selama penelitian berkisar antara $56,50 \%$ 
sampai dengan $67,50 \%$, dan rata-rata curah hujan selama penelitian berkisar antara $274 \mathrm{~mm}$ sampai dengan $584 \mathrm{~mm}$. Menurut Andoko (2002) kelembaban udara yang diinginkan untuk tanaman padi berkisar 60\%-85\% dan curah hujan $200 \mathrm{~mm}$ per bulan atau lebih

\section{KESIMPULAN}

Dari hasil penelitian yang telah dilakukan dapat disimpulkan sebagai berikut :

1. Aplikasi kombinasi perlakuan kompos tandan kosong kelapa sawit, lumpur laut dan biochar sekam padi hanya berpengaruh nyata terhadap variabel pengamatan jumlah anakan produktif.

2. Aplikasi perlakuan terhadap sifat kimia tanah $(\mathrm{pH}, \mathrm{C}$-organik, KB, KTK, N, $\mathrm{P}$ dan $\mathrm{K}$ ) dan pertumbuhan serta hasil tanaman padi (tinggi tanaman produktif, hasil per petak dan berat 1000 butir) menunjukaan pengaruh yang tidak nyata. Untuk pengamatan terhadap sifat kimia tanah perlakuan t2 memberikan hasil tertinggi untuk variabel $\mathrm{pH}$ tanah $(4,81)$, perlakuan t4 memberikan hasil tertinggi untuk variabel C-organik $(8,31 \%)$, KTK $\left(31,58 \mathrm{cmol}(+) \mathrm{kg}^{-1}\right)$ dan $\mathrm{N} \quad(0,88 \%)$, perlakuan t8 memberikan hasil tertinggi untuk variabel Kejenuhan basa (26.63\%) dan P tersedia (18,35 ppm), dan perlakuan t9 memberikan hasil tertinggi untuk variabel $\mathrm{K}$ tanah $(0,253 \mathrm{cmol}(+) \mathrm{kg}-1)$.
3. Aplikasi perlakuan terhadap pertumbuhan dan hasil tanaman pada variabel tinggi tanaman, hasil per petak, dan berat 1000 butir padi juga menunjukkan pengaruh yang tidak nyata.

4. Perlakuan t3 memberikan hasil tertinggi untuk variabel tinggi tanaman $(67,67 \mathrm{~cm})$ dan jumlah anakan produktif (18,58 anakan), perlakuan $\mathrm{t} 8$ memberikan hasil tertinggi untuk variabel hasil per petak $(346,333 \mathrm{~g}) \mathrm{cm})$, perlakuan $\mathrm{t} 9$ memberikan hasil tertinggi untuk variabel berat 1000 butir $(24.989 \mathrm{~g})$.

\section{UCAPAN TERIMAKASIH}

Penulis mengucapkan terimaksih kepada Kemeristekdikti yang telah membantu pendanaan sehingga penelitian ini dapat telaksana

\section{DAFTAR PUSTAKA}

AAK. 1990. Budidaya Tanaman Padi. Kanisius. Yogyakarta.

Alwi,M., Sabiham, S. Anwar, Suwarno, Achmadi, 2010. Pelindian Tanah Balandean Kalimantan Selatan pada beberapa Kondisi potensial redoks Menggunakan air Insitu, Jurnal Tanah dan Iklim, No 32, Desember.

Adwa, T.Y.I. dan Nelvia, 2014., Pengayaan Kompos Tandan Kosong Kelapa Sawit (TKKS) dengan Spent Earth Terhadap Pertumbuhan dan Hasil Kedelai (Glycine max) di Lahan Gambut, Jurnal Jom Faperta, Volume 1 No. 2.

Chari K, Manjunantha dan Ravi M.V., 2013. Evaluation of Quality and Nutrient Status of Enriched Compost, Jurnal of Agriculture and Veterinary Science (IOSR-JAVS), Volume 6, Issue 2. 
Ginting, E.N., F. Hidayat, dan H. Santoso, 2011. Substitusi Pupuk MoP dengan Tandan Kosong Kelapa Sawit pada Perkebunan Kelapa Sawit Di Ultisol. Jurnal Penelitian Kelapa Sawit, Vol 19 No.1 , Pusat Penelitian Kelapa Sawit, Medan.

Hayat, E.S dan S. Andayani, 2014., Pengelolaan Limbah Tandan Kosong Kelapa Sawit dan Aplikasi Biomassa Chromolaena odorata terhadap Pertumbuhan dan Hasil Tanaman Padi serta Sifat Tanah Sulfaquent, Jurnal Teknologi Pengelolaan Limbah, Volume 17, No. 2, Desember 2014, PTLR BATAN.

Haryono 2013., Strategi Kebijakan Kementerian Pertanian dalam Optimalisasi Lahan Suboptimal Mendukung Ketahanan Pangan Nasional, Prosiding Seminar Nasional Lahan Suboptimal, Palembang.

Khairullah,I., D. Indradewa, P. Yudono, A. Maaz. 2011. Pertumbuhan dan Hasil Tiga Varietas Padi pada Perlakuan Kompos Jerami dan Purun Tikus (Eleocharis dulcis) di Tanah Sulfat Masam. Jurnal Agroscientiae Vol 18.

Kementerian Pertanian, 2014., Pertumbuhan Areal Kelapa Sawit, Direktorat Jenderal Perkebunan, Jakarta.

Laboratorium Kimia dan Kesuburan Tanah UNTAN, 2014. Analisis Tandan Kosong Kelapa Sawit, Pontianak.

Majerus, V., P.Bertin, S. Lutts, 2007. Effect of Iron toxicity in Osmotic Potential, Osmolytes and polyamines Concentration in African rice (Oryza glaberrima Stued), Plant Science, Vol 173

Masulili, A. , Wani Hadi Utomo, dan Syecfani MS, 2010. Rice Husk Biochar for Rice Based Cropping System in Acid Soil 1: The Characteristics of Rice Husk Biochar and Its Influence on the Properties of Acid Sulfate Soil and Rice Growth in West Kalimantan,
Indonesia. Journal of Agricultural Science, Vol 2, No.1.

Masulili, A. Suryantini, A.Tutik PI., 2014., Pemanfaatan Biochar untuk Memperbaiki Beberapa Sifat Tanah Sulfat Masam Sungai Kakap, Kalimantan Barat. Prosiding Seminar Nasional Inovasi Teknologi Pertanian Spesifik Lokasi, Badan Penelitian dan Pengembangan Pertanian.

Noor, M .,A.Maaz, T. Notohadikusumo, 2008. Pengaruh Pengeringan dan Pembasahan terhadap Sifat Kimia Tanah Sulfat Masam Kalimantan, Jurnal Tanah dan Iklim, Vol 27.

Prayitno, S, D. Indradewa, B.H. Sunarminto, 2008., Produktivitas Kelapa Sawit (Elaeis guineensis Jacq) yang dipupuk dengan Tandan Kosong dan limbah Cair Kelapa Sawit. Jurnal Ilmu Pertanian Vol 15 No1.

Priatmadi, B.J. A. Haris, 2008. Reaksi Pemasaman Senyawa Pirit Pada Tanah Rawa Pasang Surut, Jurnal Tanah Tropik, Vol 14.

Purnomo, E. A. Mursyid, M. Syarwani, A. Jumberi, Y Hashidoko, T. Hasegawa S, Homna, dan M. Osaki, 2005, Phosphorus solubilizing microorganisme in the Rhizosfer of local rice Varities Grown without Fertilizer on Acid Sulphate Soil. Soil Sci. Plant Nutr, Vol 51(5)

Sokchea, H., Khieu Borin, TR Preston, 2013. Effect of Biochar from Rice Husk (combusted in a downdraft gasifier or a paddy rice dryer) on Production of Rice Fertilized with Biodegester Effluent or Urea, Livestrock Research for Rural Developmen 25 (1) 2013.

Suhardjo, H, Suratman, T. Prihatini, dan S. Ritung, 2000., Lahan Pantai dan Pengembangannya. Sumber daya lahan Indonesia dan Pengelolaannya, Pusat Penelitian Tanah dan Agroklimat, Bogor.

Sulistyowati, H dan Denah Suswati, 2010, Pengaruh Lumpur Laut Terhadap 
Ketersediaan Kation-kation Basa pada Tanah Gambut untuk Budidaya Tanaman Melon (Cucumis melo L), Jurnal Penelitian Universitas Tanjungpura, Volume XVIII No. 2, April 2010.

Suriadikarta, D.A. @005, Pengelolaan Lahan Sulfat Masam untuk Usaha Pertanian, Jurnal Litbang Pertanian, Vol 24.

Widjaja-Adhi, IPG., D.A. suriadikarta, MT. Sutriadi, I GM. Subiksa, dan I.W. Suastika, 2000., Pengelolaan,
Pemanfaatan dan Pengembangan Lahan Rawa, Pusat Penelitian Tanah dan Agroklimat, Bogor.

Zhang, A., Rongjun Bian, Genxing Pan, Liqiang Cui, Qaiser Hussain, Lianqing Li, Jinwei Zheng, Jufeng Zheng, Xuhui Zhang, Xiaojun Han, Xinyan Yu., 2012, Effect of biochar amendement on soil quality, crop yield and reenhouse gas emission in a Chinese rice paddy : A field of 2 consecutive rice growing cycles. Field Crops Research 127 (2012) 